\title{
CONSTITUTIONAL RIGHTS FOR PERSONS WITH DISABILITIES IN INDONESIA: PRESENT AND FUTURE REGULATIONS (A Comparative Perspective between Indonesia and Malaysia)
}

\author{
Indri Sukmawati Djangko \\ Faculty of Law, Brawijaya University \\ Email: indridjangko@gmail.com
}

\begin{abstract}
Recognition of similar rights between persons with disabilities and common people has become a global issue. The world has been realized this point and initiated some international programs to fight the rights for persons with disabilities. Indonesia has already recognized the disabilities people rights in constitution and other regulation. Contrary to the fact that the awareness of human right fulfillment for person with disabilities is already contained in Indonesian regulations, its realization is not enough to guarantee the welfare and human rights fulfillment for every person with disabilities. Through library research which is used as a method of data collection in this paper, the author compares the fulfillment of human rights for persons with disabilities in Indonesia and Malaysia. In this paper, the author explains constitutional rights that support the human rights' existence for persons with disabilities, as well as describes the rights that are mandated in every level of regulation hierarchy that specifically regulating persons with disabilities. In the end, this paper also suggests alternative solution for Indonesia in the future.
\end{abstract}

Keywords: disabilities, rights, Indonesian Law, Malaysian Law

\section{INTRODUCTION}

Constitutional rights are important issues contained directly in modern constitution ${ }^{1}$. It is an obligation, not only for every citizen to apply it in their life - both as individual and as social being-but also for government as the main stakeholder in

1 Presented at the Public Dialogue and the National Consultative Commission of Women "Women and the Constitution in the Era of Regional Autonomy: Challenges and Attitude Together". Jakarta, 27 November 2007 by the Chairman of the Constitutional Court, Jimmly Ashidiqie. hierarchical state structure. Indonesia as a state with the ideology of Pancasila also upholds respect for human rights. Each principle of Pancasila indicates respect for every individual human being. Pancasila is a hierarchy in a form of pyramid ${ }^{2}$; it illustrates

\footnotetext{
${ }^{2}$ According to Notonegoro, the five principles of Pancasila was an inseparable unity and should not be turned upside down without changing the core contents. Interpreted as a series of hierarchical levels in the breadth of content, while the pyramidal shape because every precept that there is more under the specialization of morality in it. Above precepts are the basis, meaning and inspiration subsequent
} 
a strong, inseparable, and interrelated connection between each of its principles. Therefore, all of the principles must be embodied comprehensively. To be exact, the spirit of Pancasila boils down to uphold human rights without exception, including persons with disabilities ${ }^{3}$.

Recognition of similar rights between persons with disabilities and common people has become a global issue. The world has been realized this point and initiated some international programs to fight the rights for persons with disabilities. According to the recognition of human rights for persons with disabilities' chronology ${ }^{4}$, there was a long journey to

precepts. More see P.J. Suwarno, Pancasila Indonesian National Culture, Canisius, 1993, p. 87. 3 Earlier, before the term "persons with disabilities" is used, other terms refer to people who do not lack the physical and mental abilities, such as: "the disabled". To respect the people, in Bahasa Indonesia the term "the disabled" has been replaced with "persons with disabilities". This terminology has officially declared at the time of ratification CPRD official translation of "person with disability" is people with disabilities. More see Eva Rahim Kasim,

Chronological Efforts Ratification The Convention on the Rights of Persons With Disabilities in Indonesia, paper presented at Seminar Day of CRPD and its' Implementation in Form Inclusive Local Development Policy in West Sumatra, Padang, February 4, 2013. https: // www.academia.edu/4728310/KRONOLOGIS_UPA YA_RATIFIKASI_THE_CONVENTION_ON_THE _RIGHTS_OF_PERSONS_WITH_DISABILITIES_ KONVENSI_HAK-

HAK_PENYANDANG_DISABILITAS_DI_INDON ESIA_Oleh_Eva_Rahmi_Kasim realize an international convention, namely The Convention on The Rights of Persons with Disabilities (CRPD). Up to now, CRPD is the spearhead for the human rights recognition of persons with disabilities and its fulfillment in some states around the world. Indonesia has ratified this convention in the Law No. 19 of the year 2011 on Ratification of Convention upon the Rights of Persons with Disabilities. In Indonesian regulation, especially on Indonesian Basic Constitution of Undang-Undang Dasar Negara Republik Indonesia Tahun 1945, there is a regulation about similar rights for every citizen without exception. This is contained in the preambule (opening part) as one purpose of the nation. This point is also contained in Chapter IX of Undang-Undang Dasar Negara Republik Indonesia Tahun 1945 about Human Rights ${ }^{5}$. This regulation of human rights applies generally for every citizen, including persons with disabilities. To implement the mandate of the

\footnotetext{
${ }^{5}$ In general matters set forth in Chapter IX of the Constitution of RI 1945 on Human Rights included: the right to survive (28 A), forming a family and continue the descent without discrimination (28 B), self-development through the fulfillment of basic needs (28 C), rights of legal certainty, greeting opportunity in government, and citizenship (28 D), freedom of religion (28 E), the right to communicate $(28 \mathrm{~F})$, the protection of self and family in terms of honor, property, free from threats, torture and degrading treatment $(28 \mathrm{G})$, welfare $(28 \mathrm{H})$, and the right to independence in life, thought and conscience (28 I)
} 
constitution, regulations under UndangUndang Dasar Negara Republik Indonesia Tahun 1945 also regulates the rights of person with disabilities. Before the ratification of CRPD in Indonesia, there were some regulations about persons with disabilities, such as Law No. 39 Year 1999 on Human Rights and Law No. 4 Year 1997 on Person with Disabilities

In international context, just before and after the convention of CRPD, there were real actions to express the need of human rights fulfillment for persons with disabilities. One of the examples is the 1993 Vienna Convention. In this convention, there was an urgent necessity for governments to facilitate the needs of persons with disabilities - one of them was in the field of policy-making and planning. This section described that all states must: a) initiate and plan adequate policies in national level; stimulate and support action at regional and local levels; b) get involve in organizations of PWDs on all decisionmaking relating to their interests; c) incorporate the needs and concerns of persons with disabilities into general development plans and not to treat it separately; d) provide public services to be easily accessed by persons with disabilities in their activities; e) facilitate the programs development and evaluation by local communities. ${ }^{6}$ Australia includes disabilities program as the main national achievement that has a clear legislation basis, program principle, development priority, corresponding time with the mainframe, founding stages and another work steps that appropriate with its national needs ${ }^{7}$. This issue has also been done by one of ASEAN state-Malaysia-which has complete stages of founding, starts from the wisdom regulation until the comprehensively planned application for their citizen life ${ }^{8}$.

Contrary to the fact that the awareness of human right fulfillment for person with disabilities is already contained in Indonesian regulations, its realization is not enough to guarantee the welfare and human rights fulfillment for every person with disabilities. According to the data of PUSDATIN from Indonesian Social Ministry, the number of person with

6 Rebecca Wallace, International Human Rights Text and Materials, London: Sweet \& Maxwell, 1997, page 278.

${ }^{7}$ Social Ministry of Australia, Planning assessment urgent cases http://www.ndis.gov.au /sites/default/files/documents/og_planning_assessme nt urgent_cases.pdf Publication date: 9 December 2013 diakses pada tanggal 28 Oktober 2014

${ }^{8}$ Abdul Munawar, Malaysia dan Australia, Surga bagi Kaum Disabilitas, http://health.liputan6 .com/read/771028/malaysia-dan-australia-surga-bagikaum-disabilitas. Diakses pada tanggal 28 Oktober 2014 
disabilities in Indonesia is approximately 11,580,117 persons. Among this number includes 3,474,035 blind people, 3,010,830 physically disabled people, 2,547,626 people with hearing disabilities, 1,389,614 mentally disabled people and 1,158,012 chronically disabled people. Furthermore, according to the data from Indonesian Manpower and Transmigration Ministry, in 2010 the number of person with disabilities was around $7,126,409$. The inaccurate data on the number of persons with disabilities hampered some actions to be performed. Moreover, there is also no accurate data about public facilities for persons with disabilities provided by the government ${ }^{9}$. Besides, laws on special access for persons with disabilities are still unable to accommodate equality for every citizen ${ }^{10}$. It is somehow worsened by the lack of social guarantee for citizen with disabilities ${ }^{11}$.

${ }^{9}$ ILO,Inklusi Penyandang Disabilitas di Indonesia. $\quad$ http://www.ilo.org/wcmsp5/groups /public/---asia/---ro-bangkok/---ilo-

jakarta/documents/publication/wcms_233426.pdf

diakses pada tanggal 28 Oktober 2014

${ }^{10}$ Iffah Nur Arifah, Kesadaran Hukum Difabel Indonesia Rendah,

http://www.radioaustralia.net.au/indonesian/2014-0501/kesadaran-hukum-difabel-indonesiarendah/1303744 diakses pada tanggal 28 Oktober 2014

${ }^{11}$ Persepsi, Ribuan Orang Difabel di Klaten Tak Dapat Jaminan Sosial,http://www.persepsiklaten.org/sosial/ribuan-orang-difabel-di-klaten-takdapat-jaminan-sosial, diakses pada tanggal 28 Oktober 2014.
The discrimination on almost every aspect of the life of persons with disabilities makes the author interested in examining the rights for persons with disabilities. As citizen who recognized by positive law in Indonesia, persons with disabilities deserve appropriate treatment in accordance to the constitutional mandate and other regulations about it. It is important to consider the equal rights between persons with disabilities and other citizens. Indonesia needs to take into account some lessons from countries which already implement the fulfillment of human rights for persons with disabilities; for example, Malaysia. Through library research which is used as a method of data collection in this paper, the author compares the fulfillment of human rights for persons with disabilities in Indonesia and Malaysia. In this paper, the author explains constitutional rights that support the human rights' existence for persons with disabilities. This paper also describes the rights that are mandated in every level of regulation hierarchy that specifically regulating persons with disabilities. In the end, this paper also suggests alternative solution for Indonesia in the future.

\section{METHODE OF RESEARCH}


This paper uses juridical-normative method, including reviewing and analyzing the rules of Indonesian and Malaysian law concerning protection of disabilities rights, as well conducting a comprehensive analysis of Indonesian and Malaysian Law.

The approach in this paper is the Statute and comparative approach, which in this research will explore the comparison of law and constitution between Indonesia and Malaysia. Through library research which is used as a method of data collection in this paper, the author compares the fulfillment of human rights for persons with disabilities in Indonesia and Malaysia.

\section{RESULT AND DISCUSSION}

A. Constitutional Rights for People with Disabilities in Indonesia and Malaysia

Legally Binding Power of Constitution between Civil Law States and Common Law $\underline{\text { States }}$

Countries with common law or civil law system have their own written constitution. Furthermore, a written Constitution is the most supreme and highest law of the land, the law of laws, or the ground norm. In other words, it is the law on which all other laws rest. It has a special, higher legal status. It is the highest rule in the legal pyramid ${ }^{12}$. In common law system, the law is not produced by the legislation but it is made by courts that used their decisions as standards. Shortly, the developed principles decided by previous court must be followed. It means that the precedents ought to be respected (stare decisis principle).

In constitution theory that implemented by common law system, the main principle used by a state is this stare decisis principle or binding force of precedents principle. Although the formation of constitution in common law state still refers to legislative agreements and approval; yet in its derivative regulation this principle decides the implementation of constitution in common law countries. However, the legally binding of constitution in common law countries ought to be obeyed by its citizens comprehensively ${ }^{13}$. Malaysia as a state with common law system uses constitution as the main base to form regulation.

The power of constitution on countries with civil law is located in its written law, and thus the norms are provided in law regulation. The source of these laws

\footnotetext{
${ }^{12}$ Shad Saleem Faruqi, Document of Destiny: The Constitution of the Federation of Malaysia, Malaysia: Star Publications Berhad, 2008, p. 21 ${ }^{13}$ Ibid
} 
is the law that is formed by legislative. The written constitution on countries with civil law is meant to give direction to its derivative regulation so that it can be regulated systematically with specific codification or compilation. Adoption to the main principle becomes reflection of the main purpose of law-legal certainty.

Human Rights in Malaysia and Indonesia's $\underline{\text { Constitution }}$

Before the amendment, UUD NRI 1945 did not explicitly mention the issue of human rights. Human rights in constitution were mentioned generally, not in precise details. Later on after the amendment, especially after the second amendments of UUD NRI 1945 in 2000, the provision of human rights was changed. Prior material of human rights in UUD NRI 1945 which contained seven points of human rights provision were changed into a more detailed provision of human rights. By ratification of the second amendment in 2000, the basic provision of human rights in UUD NRI 1945 were shown in Article 28A paragraph (1) until Article 28J paragraph (2):

1) Everyone has the right to live and to survive in his/her life. Article 28A paragraph (1) can be divided into two parts, namely: (i) each person has the right to live; and (ii) each person has the right to survive in his/her life.

2) Everyone has the right to start a family and to have descendant through legal marriage. Article 28B paragraph (1) can be divided into two parts, namely: (i) each person has the right to start a family through legal marriage; and (ii) every person entitles to continue his/her descendant through legal marriage;

3) Every child has the right to live, to grow, and to develop, and is entitled to protection from violence and discrimination. The provision of Article 28B paragraph (2) contains two principles, namely: (i) Every child has the right to live, to grow, and to develop; and (ii) Every child has the right to be protected from violence and discrimination.

4) Everyone has the right to develop themselves through the fulfillment of their basic needs; and the rights to get education and to get benefits from science and technology, art and culture, in order to improve the quality of their life and for the 
welfare of mankind. Article 28C paragraph (1) can also be divided into several principles, namely: (i) each person has the right to develop themselves through the fulfillment of basic needs in order to improve their life quality and for the welfare of mankind; (ii) each person entitles to education in order to improve their life quality and for the welfare of mankind; (iii) each person entitles to receive the benefits of science and technology, art and culture, in order to improve their life quality and for the welfare of mankind

5) Everyone has the right to promote themselves in a struggle for their rights collectively to build their community, nation, and country;

6) Everyone has the rights of fair recognition, guarantee, protection, and legal certainty and equal treatment before the law. The right to be recognized as a person before the law is shown in Article 28 paragraph (1) as a human right that cannot be reduced under any circumstances;

7) Everyone has the right to work, earn rewards, and receive fair and proper treatment in their employment;
8) Every citizen shall have equal opportunities in the governance;

9) Everyone has the right of citizenship;

10) Everyone is free to embrace any religion and to do worship of their belief, to choose education and teaching, employment, citizenship, choosing a place to stay in the state and to leave, and has the right to return. Section 28E (1) can be broken down into several principles, namely: (i) each person is free to embrace any religion and to do worship of their belief; (ii) each person is free to choose education and teaching; (iii) each person is free to choose any occupation; (iv) each person is free to choose citizenship; (v) each person is free to choose a place to stay in the state, to leave, and deserve the right to return;

11) Everyone has the right to have faith of their belief, and to express their mind and attitude based on his/ her conscience;

12) Everyone has the right to have freedom of association (freedom of association), freedom of assembly (freedom of peaceful assembly), and 
freedom of expression (freedom of expression);

13) Everyone has the right to communicate and to obtain information to develop personal and social environment, as well as the right to seek, obtain, possess, store, process, and convey information by using all available channels. This provision can be divided into two parts, namely (i) every person has the right to communicate and obtain information in order to develop personal and social environment, (ii) any person has the right to seek, obtain, possess, store, process, and convey information by using all kinds of available channels;

14) Everyone has the right to protect him/herself, his/ her family, his/ her honor, dignity, and property under his/ her own control; as well as the right to be secured and protected from threats to do or not to do something related to their human right. Article 28G (1) can be divided into two parts, namely: (i) any person has the right of protection for his/ herself, family, honor, dignity, and property under his control; and (ii) any person has the right to security and protection from threats to do or not to do something that is a human right;

15) Everyone has the right to be free from any torture or degrading treatment of human dignity and the right to obtain political asylum in another state. Section 28G (2) can be divided into two, namely (i) every person has the right to be free from torture or other inhuman and degrading treatment, and (ii) any person has the right to obtain political asylum in another state;

16) Everyone has the right to live prosperously both physically and spiritually; to settle; to live in a good and healthy environment; and to get proper medical care;

17) Everyone is entitled to have access and special treatment to obtain fair opportunities and benefits to achieve equality and justice;

18) Everyone has the right of social security that allows development of him or herself as human being with dignity;

19) Everyone has the right to own private property; thus, property 
rights should not unfairly be taken over by others;

20) Everyone has the right to live, not to be tortured, to own the freedom of thought and conscience, freedom of having faith in any religion, freedom from enslavement, recognition as a person before the law, and the right not to be prosecuted under retroactive laws. These are the human rights that cannot be reduced under any circumstances, which later can be broken down into seven kinds of human rights, namely that every person has: (i) the right to life; (ii) the right not to be tortured; (iii) the right to freedom of thought and conscience; (iv) the right to freedom of having faith in any religion; (v) the right not to be enslaved; (vi) the right to recognition as a person before the law; and (vii) the right not to be prosecuted under retroactive laws;

21) Everyone is entitled to be free and protected from any discriminatory treatment;

In order to enforce provision of the rights mentioned above, the set of laws on the obligation of others to respect other people's rights and responsibilities of nations on the enforcement of human rights:

1) The state guarantees the independence of each citizen to embrace their own religion and to worship according to his religion and his belief; ${ }^{14}$

2) Cultural identity and traditional rights are respected in tune with the times and civilizations; ${ }^{15}$

3) The protection, promotion, enforcement and fulfillment of human rights becomes responsibility of the state, especially the government; ${ }^{16}$

4) To uphold and protect human rights in accordance with the principles of a democratic constitutional state, the practice of human rights are guaranteed, regulated, and set forth in the legislation; ${ }^{17}$

5) Every person shall respect the others' human rights in an organized society, nation, and state; ${ }^{18}$

\footnotetext{
${ }^{14}$ Article 29 (2) UUD 1945

${ }^{15}$ Article 28I (3) UUD 1945

${ }^{16}$ Article 28I (4) UUD 1945

${ }^{17}$ Article 28I (5) UUD 1945

${ }^{18}$ Article 28J (5) UUD 1945
} 
6) In carrying out their rights and obligations, everyone shall be subject to the restrictions set forth by law. This is solely for the purpose of protecting recognition and respect for the others' rights and freedoms, and to meet the demands that are appropriate to the moral considerations, religious values, security, and community structure in a democratic society; ${ }^{19}$

Moreover, in the formulation of the 1945 post-change, there are additional chapters in Section 28A to Article 28J which contain provisions related to human rights. The provision attributed to human rights is also written in Article 29 paragraph (2), "the State guarantees the independence of each citizen to embrace their own religion and to worship according to his religion or belief it ". This article can be said as the most qualified human rights clause; since it is inherited from the original manuscript of the 1945 Constitution. While other provisions, such as Article 27 paragraph (1) and (2), Article 28, Article 30 paragraph (1), Article 31 paragraph (1), and Article 32 paragraph

${ }^{19}$ Article 28J (1) UUD 1945
(1) and (2) is not a provision on human rights guarantees in its true sense, yet with regard to understanding the rights of citizens. ${ }^{20}$ Ketentuan-1945 provisions may include basic principles as follows:

1) Everyone has the right to life; ${ }^{21}$

2) Everyone has the right to defend life and living; ${ }^{22}$

3) Everyone has the right to start a family through legal marriage; ${ }^{23}$

4) Everyone has the right to continue his/ her descendant through a legal marriage, ${ }^{24}$

5) Every child has the right to live, to grow, and to develop;

6) Every child has the right to protection from violence and discrimination;

7) Everyone has the right to develop themselves through the fulfillment of basic needs, in order to improve the quality of

\footnotetext{
${ }^{20}$ See Senate Document 99-16, "The Constitution of the United States of America, Analysis and Interpretation", pages 956, 957, footnote 12. See http: //www.chronon hotonthologos.com /lawnotes/pvcright.htm

${ }^{21}$ Article $28 \mathrm{~A}$ point 1 , the right to live according to the provisions of Article 28 paragraph (1) UUD 1945 shall include categories of rights that cannot be reduced under any circumstances

22 Ibid. Article 28 A point 2

${ }^{23}$ Article 28B (1) UUD 1945

${ }^{24}$ Ibid.
} 
life and for the welfare of mankind; ${ }^{25}$

8) Everyone has the right to education, in order to improve the quality of life and for the welfare of mankind.

9) Everyone has the right to obtain the benefits of science and technology, arts and culture, in order to improve the quality of life and for the welfare of mankind;

10) Everyone has the right to stand up for his/ her rights collectively to build a community, nation, and country; ${ }^{26}$

11) Everyone has the right of recognition, security, protection, legal certainty and fair treatment before the law; ${ }^{27}$

12) Everyone has the right to work, to earn rewards, to receive fair treatment and to have decent working relationships; ${ }^{28}$
${ }^{25}$ Article 28C (1) UUD 1945

${ }^{26}$ Article 28C (2) UUD 1945

${ }^{27}$ Article 28D (1) UUD 1945

${ }^{28}$ Article 28D (2) UUD 1945
13) Every citizen shall have equal opportunities in the government; ${ }^{29}$

14) Everyone has the right of citizenship ${ }^{30}$

15) Everyone is free to embrace religion and to worship according to their religion; ${ }^{31}$

16) Everyone is free to choose his/ her education and teaching; ${ }^{32}$

17) Everyone is free to choose any occupation;

18) Everyone is free to choose citizenship;

19) Everyone has the right to choose a place to stay in the country, to leave it, and to return again to the state;

20) Everyone has the right of freedom to have faith, to express thoughts and attitudes, in accordance with his conscience ${ }^{33}$
29 Article 28D (3) UUD 1945. However, this provision only applies to citizens of Indonesia, so it should not be understood in the context of the definition of human rights.

${ }^{30}$ Article 28D (4) UUD 1945

31 Article 28E (1) UUD 1945 This right belonged to the human rights that can not be reduced under any circumstances

${ }^{32}$ Ibid.

33 Article 28E (2) UUD 1945. This provision according to Article 28 (1), including human rights 
21) Everyone has the right of freedom of association; ${ }^{34}$

22) Everyone has the right of freedom of peaceful assembly;

23) Everyone has the right of freedom of expression ${ }^{35}$;

24) Everyone has the right to communicate and obtain information in order to develop personal and social environment;

25) Everyone has the right to seek, obtain, possess, keep, process and convey information by using all available channels;

26) Everyone has the right to defend him/ herself, family, honor, dignity, and property under his/ her control;

27) Everyone has the right to feel secured and protected from any threat or fear of to do or not to do something belongs to the human rights;

groups which can not be reduced under any circumstances

34 Article 28E (3) 1945. See also Asshiddiqie, Freedom of Association, Dissolution of Political Parties, and the Constitutional Court, Konpress, Jakarta, 2005

35 Especially with this regard to freedom of expression, according to Article 28 (1) UUD 1945 belonging to human rights can not be reduced under any circumstances
28) Everyone has the right to be free from torture ${ }^{36}$ or other degrading treatment of human dignity;

29) Everyone has the right to obtain political asylum from another country;

30) Everyone has the right to live in physical and spiritual prosperity;

31) Everyone is entitled to settle (properly and healthy);

32) Everyone deserves a good environment and healthy;

33) Everyone has the right to obtain medical care $; 3$

34) Everyone is entitled to special treatment facilities and to obtain the same opportunities and benefits in order to achieve equality and justice, ${ }^{38}$

35) Everyone has the right to social security that allows the

${ }^{36}$ The right not to be tortured, according to Article 28 (1) UUD 1945, including human rights groups which can not be reduced under any circumstances

${ }^{37}$ Article 28H (1) UUD 1945

${ }^{38}$ Article 28H (2) UUD 1945. Principles set out here is the provision of special treatment called "affirmative action" as positive discrimination. Special treatment in the form of positive discrimination is deemed acceptable as long as intended for the purpose of achieving equality and justice as intended by this article 28H (2) UUD 1945. Compare with Erwin Chemerinsky, Constitutional Law: Principles and Policies, Aspen Law and Business, New York, 1997, p. 585 
development of him or herself as

a human being with dignity; ${ }^{39}$

36) Everyone has the right to have private property rights and property rights should not be taken over arbitrarily by anyone ${ }^{40}$

37) Everyone has the right to life; ${ }^{41}$

38) Everyone has the right not to be tortured; ${ }^{42}$

39) Everyone has the right to freedom of thought and conscience $;{ }^{43}$

40) Everyone has the right to freedom of religion; ${ }^{44}$

41) Everyone has the right not to be enslaved; ${ }^{45}$

42) Everyone has the right to recognition as a person before the law; ${ }^{46}$

\footnotetext{
${ }^{42}$ Ibid.

${ }^{43}$ Ibid.

${ }^{44}$ Ibid.

${ }^{45}$ Ibid.
}

${ }^{39}$ Article 28H (3) UUD 1945

${ }^{40}$ Article 28H (4) UUD 1945

41 These rights are set out in Article 28 (1) UUD 1945 as a human right that can not be reduced under any circumstances, which includes seven kinds of human rights, namely that every person has: (i) the right to life; (ii) the right not to be tortured; (iii) the right to freedom of thought and conscience; (iv) the right to freedom of religion; (v) the right not to be enslaved; (vi) the right to recognition as a person before the law; and (vii) the right not to be prosecuted based on retroactive laws
43) Everyone has the right not to be prosecuted on the basis of retroactive laws; ${ }^{47}$

44) Everyone is entitled to be free from discriminatory treatment on any basis; ${ }^{48}$

45) Everyone has the right to protection against discriminatory treatment of it; ${ }^{49}$

Various provisions already made in the formulation of the 1945's are substances derived from the formulation of the Decree No.XVII / MPR / 1998 on Human Rights, which was later transformed into a matter of Law 39 Year 1999 on Human Rights. Therefore, to understand whether it was a controlled substance in 1945, two related instruments, namely TAP MPR No. XVII / MPR / 1998 and Law No. 39 of 1999 should

${ }^{46} \mathrm{Ibid}$

${ }^{47} \mathrm{Ibid}$

${ }^{48}$ This provision is also referred to as the principle of "equal protection". However, in its development, this principle also recognizes the existence of an exception in the form of "affirmative action". In practice in the United States, this exception is recognized as the "racial classifications benefiting minorities", see Erwin Chemerinsky, op.cit., P. 585, or in the "gender classifications benefiting women", Ibid., P. 609. "affirmative action" as this would be viewed as a human right as well that should be protected by the provisions of Article 28H (2) UUD 1945

${ }^{49}$ Article 28I (2) UUD 1945 
also carefully be studied. ${ }^{50}$ Hence, in general it can be said that the provisions on human rights which has been adopted into Indonesian legal system is derived from international conventions and the universal declaration of human rights, as well as various other international legal instruments. ${ }^{51}$ It includes ratification of accessibility for persons with disability.

Unlike Indonesia, Malaysia with its constitutional alliance owns a system to set their citizen's rights which is contained at many articles in its constitution. It includes Part II of the constitution of Malaysia about fundamental liberties of Malaysian citizen:

\section{Article 5}

(1) No person shall be deprived of his life or personal liberty save in accordance with law.

(2) Where complaint is made to a High Court or any judge thereof that a person is being unlawfully detained the court shall inquire into the complaint and, unless satisfied that the detention is lawful, shall order him to be produced before the court and release him.

(3) Where a person is arrested he shall be informed as soon as may be of the grounds of his arrest and shall be

\footnotetext{
${ }^{50}$ See Satya Arinanto, Human Rights in Political Transition in Indonesia, FHUI HTN Study Center, Jakarta, 2003, hal.21-30

${ }_{51}$ Read Peter Baehr, Pieter van Dijk et al, eds, Principal International Instruments on Human Rights, Yayasan Obor Indonesia, Jakarta, 2001.
}

allowed to consult and be defended by a legal practitioner of his choice.

(4) Where a person is arrested and not released he shall without unreasonable delay, and in any case within twentyfour hours (excluding the time of any necessary journey) be produced before a magistrate and shall not be further detained in custody without the magistrate's authority:

Provided that this Clause shall not apply to the arrest or detention of any person under the existing law relating to restricted residence, and all the provisions of this Clause shall be deemed to have been an integral part of this Article as from Merdeka Day.

(5) Clauses (3) and (4) do not apply to an enemy alien.

\section{Article 6}

(1) No person shall be held in slavery.

(2) All forms of forced labour are prohibited, but Parliament may by law provide for compulsory service for national purposes.

(3) Work incidental to the serving of a sentence of imprisonment imposed by a court of law shall not be taken to be forced labour within the meaning of this Article.

(4) Where by any written law the whole or any part of the functions of any public authority is to be carried on by another public authority, for the purpose of enabling those functions to be performed the employees of the first mentioned public authority shall be bound to serve the second mentioned public authority shall not be taken to be forced labour within the meaning of this Article, and no such employee shall be entitled to demand any right from either the first mentioned or the second 
mentioned public authority by reason of the transfer of his employment.

\section{Article 7}

(1)No person shall be punished for an act or omission which was not punishable by law when it was done or made, and no person shall suffer greater punishment for an offence than was prescribed by law at the time it was committed.

(2) A person who has been acquitted or convicted of an offence shall not be tried again for the same offence except where the conviction or acquittal has been quashed and a retrial ordered by a court superior to that by which he was acquitted or convicted.

\section{Article 8}

(1) All persons are equal before the law and entitled to the equal protection of the law.

(2) Except as expressly authorized by this Constitution, there shall be no discrimination against citizens on the ground only of religion, race, descent or place of birth in any law relating to the acquisition, holding or disposition of property or the establishing or carrying on of any trade, business, profession, vocation or employment.

(3) There shall be no discrimination in favour of any person on the ground that he is a subject of the Ruler of the State.

(4) No public authority shall discriminate against any person on the ground that he is resident or carrying on business in any part of the Federation outside the jurisdiction of the authority.

(5) This Article does not invalidate or prohibit -

(a) any provision regulating personal law;

(b) any provision or practice restricting office or employment connected with the affairs of any religion, or of an institution managed by a group professing any religion, to persons professing that religion;

(c) any provision for the protection, wellbeing or advancement of the aboriginal peoples of the Malay Peninsula (including the reservation of land) or the reservation to aborigines of a reasonable proportion of suitable positions in the public service;

(d) any provision prescribing residence in a State or part of a State as a qualification for election or appointment to any authority having jurisdiction only in that State or part, or for voting in such an election;

(e) any provision of a Constitution of a State, being or corresponding to a provision in force immediately before Merdeka Day;

(f) any provision restricting enlistment in the Malay Regiment to Malays.

\section{Article 9}

(1) No citizen shall be banished or excluded from the Federation.

(2) Subject to Clause (3) and to any law relating to the security of the Federation or any part thereof, public order, public health, or the punishment of offenders, every citizen has the right to move freely throughout the Federation and to reside in any part thereof.

(3) So long as under this Constitution any other State is in a special position as compared with the States of Malaya, Parliament may by law impose restrictions, as between that State and other States, on the rights conferred by Clause (2) in respect of movement and residence. 


\section{Article 10}

(1)Subject to Clauses (2), (3) and (4) -

(a) every citizen has the right to freedom of speech and expression;

(b) all citizens have the right to assemble peaceably and without arms;

(c) all citizens have the right to form associations.

(2) Parliament may by law impose -

(a) on the rights conferred by paragraph

(a) of Clause (1), such restrictions as it deems necessary or expedient in the interest of the security of the Federation or any part thereof, friendly relations with other countries, public order or morality and restrictions designed to protect the privileges of Parliament or of any Legislative Assembly or to provide against contempt of court, defamation, or incitement to any offence;

(b) on the right conferred by paragraph (b) of Clause (1), such restrictions as it deems necessary or expedient in the interest of the security of the Federation or any part thereof, or public order;

(c) on the right conferred by paragraph (c) of Clause (1), such restrictions as it deems necessary or expedient in the interest of the security of the Federation or any part thereof, public order or morality.

3) Restrictions on the right to form associations conferred by paragraph (c) of Clause (1) may also be imposed by any law relating to labour or education.

(4) In imposing restrictions in the interest of the security of the Federation or any part thereof or public order under Clause (2) (a), Parliament may pass law prohibiting the questioning of any matter, right, status, position, privilege, sovereignty or prerogative established or protected by the provisions of Part III, article 152, 153 or 181 otherwise than in relation to the implementation thereof as may be specified in such law.

\section{Article 11}

(1)Every person has the right to profess and practice his religion and, subject to Clause (4), to propagate it.

(2) No person shall be compelled to pay any tax the proceeds of which are specially allocated in whole or in part for the purposes of a religion other than his own.

(3) Every religious group has the right -

(a) to manage its own religious affairs;

(b) to establish and maintain institutions for religious or charitable purposes; and (c) to acquire and own property and hold and administer it in accordance with law.

(4) State law and in respect of the Federal Territories of Kuala Lumpur and Lubuan, federal law may control or restrict the propagation of any religious doctrine or belief among persons professing the religion of Islam

(5) This Article does not authorize any act contrary to any general law relating to public order, public health or morality.

\section{Article 12}

(1)Without prejudice to the generality of Article 8, there shall be no discrimination against any citizen on the grounds only of religion, race, descent or place of birth -

(a) in the administration of any educational institution maintained by a public authority, and, in particular, the admission of pupils or students or the payment of fees; or

(b) in providing out of the funds of a public authority financial aid for the maintenance or education of pupils or students in any educational institution (whether or not maintained by a public authority and 
whether within or outside the Federation).

(2) Every religious group has the right to establish and maintain institutions for the education of children in its own religion, and there shall be no discrimination on the ground only of religion in any law relating to such institutions or in the administration of any such law; but it shall be lawful for the Federation or a State to establish or maintain or assist in establishing or maintaining Islamic institutions or provide or assist in providing instruction in the religion of Islam and incur such expenditure as may be necessary for the purpose.

(3) No person shall be required to receive instruction in or take part in any ceremony or act of worship of a religion other than his own.

(4) For the purposes of Clause (3) the religion of a person under the age of eighteen years shall be decided by his parent or guardian.

\section{Article 13}

(1) No person shall be deprived of property save in accordance with law.

(2) No law shall provide for the compulsory acquisition or use of property without adequate compensation

Based on various constitutions above, the constitutional rules try to incorporate the survival of every person into an inherent condition in the constitution of both Indonesia and Malaysia. Thus, the regulation or custom products which incorporated in the constitution of a State should be based on the substance of its constitutional rights. Consequently,
Indonesia and Malaysia have "accessibility for persons with disability" as fundamental regulations. The setting of Indonesian and Malaysian constitution always has purpose. Accordingly, the existing arrangements in each of these countries must be in conformity to the purpose of the constitution.

\section{B. Disability and The Implementation of Convention for The People with Disabilities' Ratification in Indonesia and Malaysia}

Obligation of the State to Submit International Law

Beside Constitution-of what so called the highest national law, there is international law that legally binds the state within the context of international relationship with other states. Among many aspects of international relationship, there is also regulation that binding state internationally. International law has different source of law other than national source of law, which is divided into written and unwritten source of law. One of the written sources of law is international agreements. In order to generate written international law to be applied nationally in 
a state, there is a special mechanism namely ratification $^{52}$.

Indonesia and Malaysia are states that internationally ratified some international agreements and incorporate it into a force in national law. Related to the area of human rights for persons with disabilities, these two states have ratified the Convention on the Rights of Person with Disabilities. Indonesia ratified it through Law No. 19 Year 2011 on October, 18th 2011; while Malaysia ratified it through Person with Disabilities Act 2008 on July, 7th 2008.

Generally, the CRPD that is generated by Resolution No. 1/61/106 53 contains the rights of persons with disabilities and regulate the steps to ensure the implementation of the convention. CRPD is the first international human rights instrument that comprehensively talks and gives attention to the needs of any person with disabilities. However, the arrangement

52 Ratification is the adoption of an act or contract entered into in behalf of the one ratifying by one who had no previous authority to represent the other; in other word, ratifying is the doing of the act or the making of the contract, further about ratification Ernest W. Huffcut, Elements of the Law of Agency, Beard Books, 1999 page 29

53 Udiyo Basuki, Perlindungan HAM dalam Negara Hukum Indonesia: Studi Ratifikasi Konvensi Hak-hak Disabilitas (Convention on the Rights of Person with Disabilities), SOSIO-RELIGIA, Vol. 10, No. 1 Februari 2012, page 18 of this instrument is also affected by other international law instruments on general human rights.

Indonesia and Malaysia's action to ratify and enter CRPD into national law instrument in the law structure of Indonesia and the act in Malaysia brought logical consequence. These two states must implement the material of ratification that is put into practice on some national law instruments. The ratification in these two countries is different. It is based on the specific needs of each country. The following table is the comparison of the result of CRPD ratification in Indonesia and Malaysia:

\begin{tabular}{|l|l|l|}
\hline $\begin{array}{l}\text { Comparativ } \\
\text { e Aspects }\end{array}$ & \multicolumn{1}{|c|}{ Indonesia $^{54}$} & \multicolumn{1}{|c|}{ Malaysia $^{55}$} \\
\hline $\begin{array}{l}\text { General } \\
\text { Forms of } \\
\text { the Act in } \\
\text { each } \\
\text { country }\end{array}$ & $\begin{array}{l}\text { Comprehensivel } \\
\text { y ratify this } \\
\text { aspect. Hence, } \\
\text { Law No. 19 } \\
\text { Year 2011 only } \\
\text { contains three } \\
\text { articles to } \\
\text { declare that } \\
\text { Indonesia have } \\
\text { ratified the } \\
\text { convention. The } \\
\text { explanation of } \\
\text { the law } \\
\text { generally } \\
\text { explains about } \\
\text { regulates } \\
\text { implementatio } \\
\text { n on CRPD } \\
\text { ratification } \\
\text { such as } \\
\text { registration, } \\
\text { protection, } \\
\text { rehabilitation, } \\
\text { etc. }\end{array}$ \\
of convention. \\
- The
\end{tabular}




\begin{tabular}{|c|c|c|}
\hline of the act ${ }^{56}$ & $\begin{array}{l}\text { recognition of } \\
\text { human rights } \\
\text { for persons } \\
\text { with } \\
\text { disabilities } \\
\text { (general } \\
\text { description) } \\
\text { - Statement to } \\
\text { ratify the } \\
\text { convention. } \\
\text { - Affirmation } \\
\text { on the } \\
\text { enactment of } \\
\text { the Law on } \\
\text { ratification } \\
\text { convention. } \\
\text { The principal } \\
\text { contents of } \\
\text { the } \\
\text { convention: } \\
\text { 1) the } \\
\text { opening; 2) } \\
\text { the purpose; } \\
\text { 3) The } \\
\text { obligation of } \\
\text { the state; 4) } \\
\text { the rights of } \\
\text { persons with } \\
\text { disabilities; } \\
\text { 5) The } \\
\text { national } \\
\text { implementati } \\
\text { on and } \\
\text { monitoring; } \\
\text { 6) State party } \\
\text { report and } \\
\text { the role of } \\
\text { monitoring } \\
\text { committees } \\
\text { convention } \\
\text { rights of } \\
\text { dersons with } \\
\text { - }\end{array}$ & $\begin{array}{l}\text { - } \text { National } \\
\text { Council for } \\
\text { Persons with } \\
\text { Disabilities } \\
\text { - Appointment } \\
\text { of general } \\
\text { registrar and } \\
\text { registration } \\
\text { for persons } \\
\text { with } \\
\text { disabilities } \\
\text { - Promotion } \\
\text { and } \\
\text { development } \\
\text { of the quality } \\
\text { of life and } \\
\text { wellbeing of } \\
\text { persons with } \\
\text { disabilities } \\
\text { (about } \\
\text { accessibility, } \\
\text { habilitation } \\
\text { and } \\
\text { rehabilitation } \\
\text {, health, } \\
\text { protection } \\
\text { from risky } \\
\text { situations } \\
\text { and } \\
\text { humanitarian } \\
\text { emergencies. } \\
\text { - General }\end{array}$ \\
\hline $\begin{array}{l}\text { Main points } \\
\text { of the act }\end{array}$ & $\begin{array}{l}\text { - The } \\
\text { recognition of } \\
\text { human rights for } \\
\text { persons with }\end{array}$ & \\
\hline
\end{tabular}

56 The author compares the list of existing chapters on each of the CRPD ratification of legal instruments in Indonesia and Malaysia.

57 The author compares the list of existing chapters on each of the CRPD ratification of legal instruments in Indonesia and Malaysia.

\begin{tabular}{|c|c|}
\hline & $\begin{array}{l}\text { disabilities } \\
\text { (general } \\
\text { description). } \\
\text { - Statement to } \\
\text { ratify the } \\
\text { convention. } \\
\text { - Affirmation on } \\
\text { the enactment of } \\
\text { the Law on } \\
\text { ratification } \\
\text { convention. } \\
\text { - The principal } \\
\text { contents of the } \\
\text { convention: } 1 \text { ) } \\
\text { the opening; } 2 \text { ) } \\
\text { the purpose; } 3 \text { ) } \\
\text { The obligation } \\
\text { of the state; } 4 \text { ) } \\
\text { the rights of } \\
\text { persons with } \\
\text { disabilities; 5) } \\
\text { The national } \\
\text { implementation } \\
\text { and monitoring; } \\
6 \text { ) State party } \\
\text { report and the } \\
\text { role of } \\
\text { monitoring } \\
\text { committees } \\
\text { convention } \\
\text { rights of persons } \\
\text { with disabilities }\end{array}$ \\
\hline $\begin{array}{l}\text { Main points } \\
\text { of the act }\end{array}$ & $\begin{array}{l}\text { - The } \\
\text { recognition of } \\
\text { human rights for } \\
\text { persons with } \\
\text { disabilities } \\
\text { (general } \\
\text { description). } \\
\text { - Statement to } \\
\text { ratify the } \\
\text { convention. } \\
\text { - Affirmation on } \\
\text { the enactment of } \\
\text { the Law on } \\
\text { ratification } \\
\text { convention. } \\
\text { - The principal } \\
\text { contents of the } \\
\text { convention: } 1 \text { ) }\end{array}$ \\
\hline
\end{tabular}

58 The author compares the list of existing chapters on each of the CRPD ratification of legal instruments in Indonesia and Malaysia. 


\begin{tabular}{|l|l|}
\hline & the opening; 2) \\
the purpose; 3) \\
The obligation \\
of the state; 4) \\
the rights of \\
persons with \\
disabilities; 5) \\
The national \\
implementation \\
and monitoring; \\
6) State party \\
report and the \\
role of \\
monitoring \\
committees \\
convention \\
rights of persons \\
with disabilities.
\end{tabular}

Das Sein and Das Sollen with Disabilities in $\underline{\text { Indonesia and Malaysia after the ratification }}$

CPRD (Law on ratification comparison table

CPRD Indonesia and Malaysia)

Indonesia, prior to the ratification of CRPD, has no arrangement of the Act partially recognizes rights of persons with disabilities from various aspects. However, Indonesia has Law No. 4 of 1997 on Persons with Disabilities. Based on the explanation of the Law No. 19 of 2011 on the Ratification of the Convention on the Rights of Persons with Disabilities, there are several laws and regulations in Indonesia regulating the rights of persons with disabilities, namely:

a. Law No. 4 of 1979 on Child Welfare;

b. Law No. 4 of 1997 on Persons with Disabilities; c. Law Number 39 Year 1999 on Human Rights;

d. Law No. 23 of 2002 on Child Protection;

e. Law No. 28 of 2002 on Building;

f. Law Number 13 Year 2003 concerning Manpower

g. Law Number 20 Year 2003 on National Education System;

h. Law No. 3 of 2005 on National Sports System;

i. Law No. 23 Year 2007 on Railways

j. Law No. 17 of 2008 on Voyage;

k. Law No. 1 of 2009 on Flight;

1. Law Number 22 Year 2009 on Traffic and Transportation;

m. Law Number 25 of 2009 on Public Service;

n. Law Number 36 of 2009 on Health; and

o. Act No. 13 of 2011 on Poverty Management

The recognition example of protection on the rights of persons with disabilities in the law through legislation in Indonesia is the Act No. 39 Year 1999 on Human Rights; particularly article 41, 42, and 54 which ensure accessibility for persons with disabilities:

Article 41: Every citizen has the right to social security that is 
needed for a decent life and to personal development as a whole. Every person with disability (disabilities), the elderly, pregnant women and children, are entitled to special treatment facilities; and

Article 42: Every citizen who is elderly, physically handicapped, or mentally disabled are entitled to care, education and training, and special assistance at the expense of the state, to ensure decent life and human dignity.

Article 54: Every child who is physically or mentally disabled is entitled to care, education and training, and special assistance at the expense of the state, to ensure decent life and human dignity and to boost confidence and skill to be able to participate in life within community, nation, and state.

In addition to regulation at the level of Law concerning rights of persons with disabilities, some local governments initiated supporting provision of accessibility for persons with disabilities. For example, local government of Sleman has Regulation No. 11 Year 2002 on Provision of Facilities in Public Buildings and Environment Disability and local government of Surakarta has Regulation No.
8 Year $1988 .^{59}$ Furthermore, Irwanto et al provided tabulation on regulations of persons with disabilities in Indonesia.

\begin{tabular}{|c|c|c|c|c|c|c|}
\hline No & $\begin{array}{c}\text { Fou } \\
\text { ndat } \\
\text { ion }\end{array}$ & $\begin{array}{l}\text { Difable } \\
\text { person' } \\
\text { s rights }\end{array}$ & $\begin{array}{l}\text { Lex } \\
\text { Speci } \\
\text { alis }\end{array}$ & $\begin{array}{l}\text { Require } \\
\text { mentof } \\
\text { Lex } \\
\text { Speciali } \\
\text { s }\end{array}$ & $\begin{array}{l}\text { Lex } \\
\text { Inferi } \\
\text { ori }\end{array}$ & $\begin{array}{c}\text { Requir } \\
\text { ement } \\
\text { of Lex } \\
\text { Inferio } \\
\text { ri }\end{array}$ \\
\hline \multirow[t]{2}{*}{1} & \multirow[t]{2}{*}{ 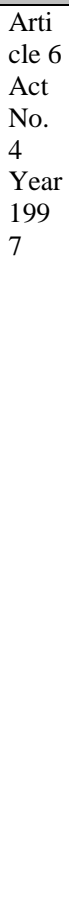 } & \multirow[t]{2}{*}{$\begin{array}{l}\text { Educati } \\
\text { on in } \\
\text { every } \\
\text { school } \\
\text { track, } \\
\text { type, } \\
\text { and } \\
\text { level of } \\
\text { educatio } \\
n ;\end{array}$} & \multirow[t]{2}{*}{$\begin{array}{l}\text { Law } \\
\text { No. } \\
20 \\
\text { Year } \\
2003 \\
\text { on } \\
\text { Natio } \\
\text { nal } \\
\text { Educ } \\
\text { ation } \\
\text { Syste } \\
\text { m }\end{array}$} & \multirow[t]{2}{*}{$\begin{array}{l}\text { Impleme } \\
\text { ntation } \\
\text { of } \\
\text { special } \\
\text { educatio } \\
\text { n for } \\
\text { citizens } \\
\text { with } \\
\text { physical } \\
\text { and } \\
\text { mental } \\
\text { disorder } \\
\text { s. }\end{array}$} & $\begin{array}{l}\text { Gover } \\
\text { nment } \\
\text { Regula } \\
\text { tion } \\
\text { No. } 10 \\
\text { Year } \\
2010\end{array}$ & $\begin{array}{l}\text { Accept } \\
\text { ance of } \\
\text { learner } \\
\text { s on all } \\
\text { levels } \\
\text { of } \\
\text { educati } \\
\text { on } \\
\text { without } \\
\text { discrim } \\
\text { ination } \\
\text { both } \\
\text { physica } \\
\text { lly and } \\
\text { mentall } \\
\text { y. }\end{array}$ \\
\hline & & & & & $\begin{array}{l}\text { Ranpe } \\
\text { rda } \\
\text { Penya } \\
\text { ndang } \\
\text { Cacat } \\
\text { (Bang } \\
\text { ka } \\
\text { Belitu } \\
\text { ng) }\end{array}$ & $\begin{array}{l}\text { Imple } \\
\text { mentati } \\
\text { on on } \\
\text { various } \\
\text { educati } \\
\text { on and } \\
\text { skills } \\
\text { for } \\
\text { people } \\
\text { with } \\
\text { disabili } \\
\text { ties. }\end{array}$ \\
\hline 2 & $\begin{array}{l}\text { Arti } \\
\text { cle } 6 \\
\text { Act } \\
\text { No. } \\
4 \\
\text { Year } \\
199 \\
7\end{array}$ & $\begin{array}{l}\text { Employ } \\
\text { ment } \\
\text { and } \\
\text { decent } \\
\text { living } \\
\text { based on } \\
\text { type and } \\
\text { degree } \\
\text { of } \\
\text { disabilit } \\
\mathrm{y}, \\
\text { educatio } \\
\mathrm{n} \text {, and } \\
\text { skill; }\end{array}$ & $\begin{array}{l}\text { Law } \\
\text { No. } \\
13 \\
\text { Year } \\
2003 \\
\text { on } \\
\text { Empl } \\
\text { oyme } \\
\text { nt }\end{array}$ & $\begin{array}{l}\text { Appropr } \\
\text { iate } \\
\text { protectio } \\
\mathrm{n} \text { based } \\
\text { on } \\
\text { disabilit } \\
\mathrm{y}, \\
\text { equality, } \\
\text { and job } \\
\text { training. }\end{array}$ & $\begin{array}{l}\text { Gover } \\
\text { nment } \\
\text { Regula } \\
\text { tion } \\
\text { No. } 43 \\
\text { Year } \\
1998\end{array}$ & $\begin{array}{l}1 \% \\
\text { quota } \\
\text { in jobs. }\end{array}$ \\
\hline 3 & $\begin{array}{l}\text { Arti } \\
\text { cle } 6 \\
\text { Act } \\
\text { No. } \\
4 \\
\text { Year } \\
199 \\
7\end{array}$ & $\begin{array}{l}\text { Fair } \\
\text { treatmen } \\
\text { t to have } \\
\text { role in } \\
\text { state } \\
\text { develop } \\
\text { ment } \\
\text { and } \\
\text { enjoy its }\end{array}$ & & & & \\
\hline
\end{tabular}

59 Ferry Firdaus and Fajar Iswahyudi, Public Services Accessibility for Person with Special Needs, 


\begin{tabular}{|c|c|c|c|c|c|c|}
\hline & & results; & & & & \\
\hline \multirow[t]{6}{*}{4} & \multirow[t]{6}{*}{$\begin{array}{l}\text { Arti } \\
\text { cle } 6 \\
\text { Act } \\
\text { No. } \\
4 \\
\text { Year } \\
199 \\
7\end{array}$} & \multirow[t]{6}{*}{$\begin{array}{l}\text { Accessi } \\
\text { bility to } \\
\text { support } \\
\text { indepen } \\
\text { dence }\end{array}$} & $\begin{array}{l}\text { Law } \\
\text { No. } \\
28 \\
\text { Year } \\
2002 \\
\text { on } \\
\text { Build } \\
\text { ing }\end{array}$ & $\begin{array}{l}\text { Mandato } \\
\text { ry } \\
\text { except } \\
\text { housing } \\
\text { accessibi } \\
\text { lity }\end{array}$ & $\begin{array}{l}\text { Gover } \\
\text { nment } \\
\text { Regula } \\
\text { tion } \\
\text { No. } 43 \\
\text { Year } \\
1998\end{array}$ & $\begin{array}{l}\text { Provisi } \\
\text { on of } \\
\text { public } \\
\text { facilitie } \\
\mathrm{s} \text { and } \\
\text { friendl } \\
\mathrm{y} \\
\text { infrastr } \\
\text { ucture } \\
\text { for } \\
\text { persons } \\
\text { with } \\
\text { disabili } \\
\text { ties }\end{array}$ \\
\hline & & & \multirow{5}{*}{$\begin{array}{l}\text { Law } \\
\text { No. } \\
28 \\
\text { Year } \\
2009 \\
\text { of } \\
\text { Traffi } \\
\text { c and } \\
\text { Trans } \\
\text { portat } \\
\text { ion }\end{array}$} & \multirow{5}{*}{$\begin{array}{l}\text { Driving } \\
\text { License } \\
\text { type } D \\
\text { and the } \\
\text { provisio } \\
\mathrm{n} \text { of } \\
\text { accessibi } \\
\text { lity in } \\
\text { public } \\
\text { transport }\end{array}$} & $\begin{array}{l}\text { Gover } \\
\text { nment } \\
\text { Regula } \\
\text { tion } \\
\text { No. } 43 \\
\text { Year } \\
1993\end{array}$ & $\begin{array}{l}\text { Giving } \\
\text { priority } \\
\text { to the } \\
\text { disable } \\
\text { d } \\
\text { vehicle }\end{array}$ \\
\hline & & & & & $\begin{array}{l}\text { Local } \\
\text { Gover } \\
\text { nment } \\
\text { Regula } \\
\text { tion } \\
\text { No. } 10 \\
\text { Year } \\
2009 \\
\text { on } \\
\text { Person } \\
\text { With } \\
\text { Disabi } \\
\text { lities } \\
\text { (Band } \\
\text { ung) }\end{array}$ & $\begin{array}{l}\text { Adjust } \\
\text { ment } \\
\text { on } \\
\text { public } \\
\text { facilitie } \\
\mathrm{s}\end{array}$ \\
\hline & & & & & $\begin{array}{l}\text { Local } \\
\text { Gover } \\
\text { nment } \\
\text { Regula } \\
\text { tion } \\
\text { No. } 6 \\
\text { Year } \\
2009 \\
\text { on } \\
\text { Person } \\
\text { With } \\
\text { Disabi } \\
\text { lities } \\
\text { (Suko } \\
\text { harjo) }\end{array}$ & $\begin{array}{l}\text { Access } \\
\text { ibility } \\
\text { of } \\
\text { Person } \\
\text { With } \\
\text { Disabil } \\
\text { ities }\end{array}$ \\
\hline & & & & & $\begin{array}{l}\text { Gover } \\
\text { nor's } \\
\text { Regula } \\
\text { tion } \\
\text { No. } 66 \\
\text { Year } \\
1981\end{array}$ & $\begin{array}{l}\text { Adjust } \\
\text { ment of } \\
\text { public } \\
\text { facilitie } \\
\mathrm{s} \text { and } \\
\text { infrastr } \\
\text { ucture } \\
\text { in } \\
\text { Jakarta }\end{array}$ \\
\hline & & & & & $\begin{array}{l}\text { Gover } \\
\text { nor's } \\
\text { Regula } \\
\text { tion } \\
\text { No. }\end{array}$ & $\begin{array}{l}\text { Adjust } \\
\text { ment of } \\
\text { public } \\
\text { facilitie } \\
\text { s and }\end{array}$ \\
\hline
\end{tabular}

\begin{tabular}{|c|c|c|c|c|c|c|}
\hline & & & & & $\begin{array}{l}140 \\
\text { Year } \\
2001\end{array}$ & $\begin{array}{l}\text { infrastr } \\
\text { ucture } \\
\text { in } \\
\text { Jakarta }\end{array}$ \\
\hline \multirow[t]{2}{*}{5} & \multirow[t]{2}{*}{$\begin{array}{l}\text { Arti } \\
\text { cle } 6 \\
\text { of } \\
\text { Act } \\
\text { No. } \\
4 \\
\text { Year } \\
199 \\
7\end{array}$} & \multirow[t]{2}{*}{$\begin{array}{l}\text { Rehabili } \\
\text { tation, } \\
\text { social } \\
\text { support, } \\
\text { and } \\
\text { mainten } \\
\text { ance of } \\
\text { social } \\
\text { welfare; } \\
\text { and }\end{array}$} & $\begin{array}{l}\text { Law } \\
\text { No. } \\
11 \\
\text { Year } \\
2009 \\
\text { on } \\
\text { Socia } \\
1 \\
\text { Welf } \\
\text { are }\end{array}$ & $\begin{array}{l}\text { Disabled } \\
\text { people } \\
\text { and } \\
\text { those } \\
\text { with } \\
\text { social } \\
\text { dysfunct } \\
\text { ion. }\end{array}$ & \multirow[t]{2}{*}{ 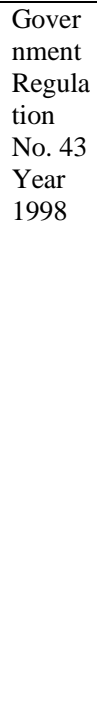 } & \multirow[t]{2}{*}{$\begin{array}{l}\text { Social } \\
\text { Welfar } \\
\text { e for } \\
\text { Person } \\
\text { With } \\
\text { Disabil } \\
\text { ities }\end{array}$} \\
\hline & & & $\begin{array}{l}\text { Law } \\
\text { No. } \\
36 \text { of } \\
2009 \\
\text { on } \\
\text { Healt } \\
\text { h }\end{array}$ & $\begin{array}{l}\text { The } \\
\text { right to } \\
\text { the } \\
\text { provisio } \\
\text { n of } \\
\text { health } \\
\text { facilities } \\
\text { and } \\
\text { governm } \\
\text { ent } \\
\text { obligatio } \\
\text { ns }\end{array}$ & & \\
\hline 6 & $\begin{array}{l}\text { Arti } \\
\text { cle } 6 \\
\text { of } \\
\text { Act } \\
\text { No. } \\
4 \text { of } \\
199 \\
7\end{array}$ & 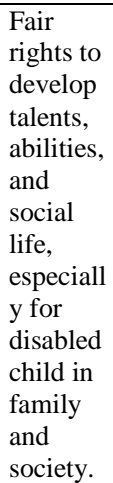 & $\begin{array}{l}\text { Law } \\
\text { No. } 1 \\
\text { of } \\
1974 \\
\text { on } \\
\text { Marri } \\
\text { age }\end{array}$ & $\begin{array}{l}\text { Divorce } \\
\text { can be } \\
\text { done in } \\
\text { case of } \\
\text { couples } \\
\text { with } \\
\text { disabilit } \\
\text { y }\end{array}$ & $\begin{array}{l}\text { Gover } \\
\text { nment } \\
\text { Regula } \\
\text { tion } \\
\text { No. } 9 \\
\text { Tahun } \\
1975\end{array}$ & $\begin{array}{l}\text { ivorce } \\
\text { can be } \\
\text { done in } \\
\text { case of } \\
\text { couples } \\
\text { with } \\
\text { disabili } \\
\text { ty }\end{array}$ \\
\hline 7 & $\begin{array}{l}\text { Act } \\
\text { No. } \\
39 \\
\text { Year } \\
199 \\
9 \text { of } \\
\text { Hu } \\
\text { man } \\
\text { Righ } \\
\text { ts }\end{array}$ & $\begin{array}{l}\text { Right to } \\
\text { participa } \\
\text { te in } \\
\text { politics } \\
\text { and law- } \\
\text { making. }\end{array}$ & $\begin{array}{l}\text { Law } \\
\text { No. } \\
10 \\
\text { Year } \\
2008 \\
\text { of } \\
\text { Electi } \\
\text { on }\end{array}$ & $\begin{array}{l}\text { Require } \\
\text { ments of } \\
\text { proficien } \\
\mathrm{t} \\
\text { speaking } \\
\text {, writing, } \\
\text { and } \\
\text { reading } \\
\text { Bahasa } \\
\text { Indonesi } \\
\text { a. }\end{array}$ & $\begin{array}{l}\text { Comm } \\
\text { ission } \\
\text { Regula } \\
\text { tion } \\
\text { No. } 13 \\
\text { of } \\
2009 \\
\text { on } \\
\text { Guidel } \\
\text { ines } \\
\text { for the } \\
\text { Imple } \\
\text { mentat } \\
\text { ion of } \\
\text { Techni } \\
\text { cal } \\
\text { Collec } \\
\text { tion } \\
\text { and } \\
\text { counti } \\
\text { ng. }\end{array}$ & $\begin{array}{l}\text { Provisi } \\
\text { on of } \\
\text { aids for } \\
\text { the } \\
\text { blinds } \\
\text { on } \\
\text { Electio } \\
\text { n. }\end{array}$ \\
\hline
\end{tabular}

Recognition on the rights of persons with disabilities in Indonesian national legal 
instruments is not enough to guarantee real actions. Various discriminatory treatments related to accessibility of public facilities occur in daily life. In fact, existing public facilities in Indonesia are not enough to support the activities of persons with disabilities. In addition, publics' negative perspective on limitations of persons with disabilities affects their confidence.

Statistic mentions that around 1.48 million people or $6.7 \%$ of Indonesia's population are living in rural areas. ${ }^{60}$ Based on this data, it can be concluded that the percentage of population of persons with disabilities in urban areas is also great. However, Indonesia has no proper data collection system. The available online system covering all statistics cannot provide easy access to data of persons with disabilities. Thus, it is hard to draw conclusion on actual number of persons with disabilities in Indonesia; to know whether it is much larger than those recorded by the statistical agency or other institutions-or not. ${ }^{61}$ Central Bureau of Statistics of the

\footnotetext{
${ }^{60}$ Ibid

${ }^{61}$ Since 1980 BPS have included disability questions in the census or survey, but in the use of the concept definition effort, the form of questions and answers, as well as the scope of the type of Questions are not fully in accordance to the mandate of CPRD and Recommendations of Washington Group, more see http: //www.bps.go.id /aboutus.php? information $=91$
}

Republic of Indonesia in 2014 committed and established cooperation with UNFPAUNICEF-WHO to provide new data collection instrument for persons with disabilities. It was introduced in the Launching of Instrument for Disability Survey. ${ }^{62}$ Establishment of a new instrument for persons with disabilities in data collection initiated by government through Central Bureau of Statistics should be appreciated as an initial effort to fulfill the rights of persons with disabilities in Indonesia. Data accuracy and data collection is therefore necessary, not only to know the exact number of Indonesian citizens with disabilities, but also as a reliable reference to determine appropriate policies and regulations in order to fulfill the rights of persons with disabilities.

There are some practical aspects need to be considered and addressed in the fulfillment of the rights of persons with disabilities which is mandated by constitution and national legal instruments. Indonesian presidential system to some extent affects system in fulfilling the rights of citizens with disabilities. The authority and duty to protect and to fulfill the rights of persons with disabilities is entrusted to

\footnotetext{
${ }^{62}$ Ibid.
} 
particular agency, such as ministry. When president is substituted, the consequences include alternation of governmental cabinet; hence, the responsible agencies including the one who responsible to fulfill the rights of persons with disabilities are also changed. Later on, these changes affect the survival of the fulfillment of the rights of persons with disabilities. For example, one affected area is the substantive funding for programs to fulfill the rights of persons with disabilities.

Didi Tarsidi in Ferry Firdaus and Fajar Wahyudi shares some architectural barriers faced by persons with disabilities.

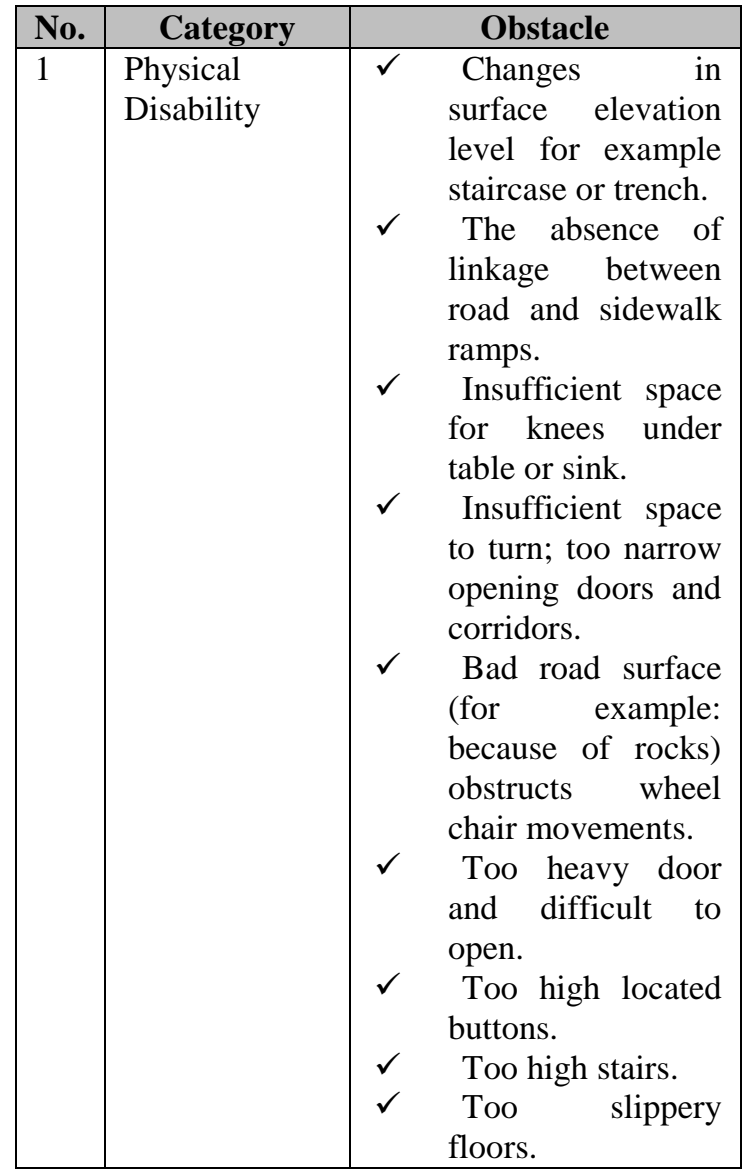

\begin{tabular}{|c|c|c|}
\hline & & $\begin{array}{l}\text { Moving quickly } \\
\text { through the } \\
\text { turnstiles or doors } \\
\text { that close } \\
\text { automatically. } \\
\checkmark \quad \text { The elevator } \\
\text { doors are closing } \\
\text { too fast. } \\
\checkmark \quad \text { The stairs run } \\
\text { without a handle } \\
\text { that moves too fast. }\end{array}$ \\
\hline 2. & $\begin{array}{l}\text { Sensory } \\
\text { Disability }\end{array}$ & $\begin{array}{l}\text { Blind: } \\
\checkmark \quad \text { The absence of } \\
\text { directions or } \\
\text { characteristics that } \\
\text { can be heard or } \\
\text { seen by people } \\
\text { with limited vision } \\
\text { that tells the } \\
\text { number of floors in } \\
\text { high-rise buildings. } \\
\text { Small obstacles } \\
\text { such as opened } \\
\text { windows or } \\
\text { mounted billboards } \\
\text { on pedestrian. } \\
\text { Blinding light or } \\
\text { too dim } \\
\text { Elevator without } \\
\text { tactual instructions } \\
\text { (palpable) to } \\
\text { distinguish buttons, } \\
\text { or voice prompts to } \\
\text { indicate floor } \\
\text { numbers. } \\
\text { Deaf: } \\
\text { People with hearing } \\
\text { impairment may find } \\
\text { difficulties in in } \\
\text { understanding on harer } \\
\text { announcement over } \\
\text { loudspeaker at airport or } \\
\text { public transportation } \\
\text { terminal. They have } \\
\text { difficulty in reading lips } \\
\text { in auditorium with poor } \\
\text { lighting and they may } \\
\text { also not be able to hear } \\
\text { alarm sound. }\end{array}$ \\
\hline 3 & $\begin{array}{l}\text { Intellectual } \\
\text { Disability }\end{array}$ & $\begin{array}{l}\text { Persons with intellectual } \\
\text { disability may find } \\
\text { difficulties in finding } \\
\text { path in new environment } \\
\text { without clear directions. }\end{array}$ \\
\hline
\end{tabular}


In Malaysia, efforts to fulfill the rights of persons with disabilities are mandated by constitution; furthermore, concrete specific deeds can been seen for example from data collection system for Persons with Disabilities, provision of facilities to support the activities of persons with disabilities, or specialization budget for Persons with Disabilities in the agenda of Malaysian annual budgeting. In 2015, the designation of Malaysian budget for Persons with Disabilities is amounted RM 1.2 billion. This fund is shared with poor families, childhood, and senior citizen. Each of the persons with disabilities is given financial assistance as much as RM350 and for those who work for unemployed persons with disabilities is given RM200. This financial assistance planned to be distributed to 110,000 persons with disabilities.

Regulation on the rights of persons with disabilities in Malaysia is not as varied in Indonesia, but these regulations provide ample details on practical service to the community of persons with disabilities in Malaysia. The deed of OKU (Malaysian term Orang Kurang Upaya or persons with disabilities) in 2008 set about OKU registration. This registration is meant for data collection and various facilities that can be obtained by persons with disabilities in public infrastructure. OKU who register will get special OKU card.

In terms of public facilities, based on author's observations in Malaysia, the kingdom and the federal government put serious concern to the accessibility of public facilities for persons with disabilities. Great attention is shown through the development of infrastructure that is "friendly" for persons with disabilities. For example, bus ramps are designed to be parallel to curb so that persons with disabilities' wheelchair can fit easily into bus; wheelchair access ramps stairs in open air facilities; special public bathrooms for persons with disabilities equipped with ramps and stairs, etc.

\section{Alternatives for Regulation of Persons with Disabilities in Indonesia}

Prior to the author's explanation, there are so many things must be considered to fulfill the mandate of constitution and national law instruments. It is also important to learn lesson from the comparison with Malaysian regulation. Therefore, the author tries to provide alternative for regulations to 
fulfill the rights of person with disabilities. Urgency of protection and fulfillment of the rights of person with disabilities should be among the first priorities in the structure of the state. This is related to the fact that number of person with disabilities in Indonesia is increasing without proper service systems to serve the basic needs of person with disabilities.

According to WHO data in 2013, the number of person with disabilities in the world in 2012 is about $15.6 \%$ from total world population or more than one billion people $^{63}$. It is known that Indonesian population now is around 247 million people; thus, by using WHO percentage it means that the total of person with disabilities in Indonesia is around 37.091.000 persons. World Bank Data mentioned that about $80 \%$ of person with disabilities that living in developing countries including Indonesia have susceptibility, backwardness, and living below the poverty line. Moreover, according to UN ESCAP Notes (2009) in Apeace (2012), around $1.38 \%$ of Indonesians are persons with disabilities (about 3,063 persons). This number is the answer from

${ }^{63}$ Pozzan E. Disability and International

Standards. Jakarta: ILO Jakarta. 2013. page 23 the government in UN-ESCAP survey in 2009 (from Susenas 2009) ${ }^{64}$.

The main trigger of marginalization and discrimination of persons with disabilities - according to Saharuddin Daming in his paper 2013 - is specifically originated from institutionalization of stereotypical attitudes, behaviors, and prejudices. It starts from general public, intellectual group, even power holders ${ }^{65}$. In accordance to this issue, it is necessary to form special regulation for persons with disabilities, which hopefully in the future can be applied in all region of Indonesia and become a part of Indonesian regulation hierarchy. Local regulation is, therefore, included in the hierarchy of national law instrument.

Local regulations are divided into two parts, namely Province Local Regulation and District Local Regulation related to the level of administrative region. Local regulations are formed by Local House of People's Representatives along with the agreement of the Head of District. Article 14 of Act No. 12 Year 2011 mentioned that Provincial Regulation and Regency/ City Regulation containing substance related to

\footnotetext{
${ }^{64}$ Ibid, page 24

${ }^{65}$ Saharuddin Daming ,. Marjinalisasi Hak Politik Penyandang Disabilitas. Penerbit Komnas HAM, Jakarta. 2012
} 
the implementation of regional autonomy and duty of assistance and to accommodate specific local conditions and/ or further elaboration of higher legislation. This Act gives an opportunity for the realization of the regulation of person with disabilities.

Prior to the explanation about holding requirement of programs to support the fulfillment of the rights of persons with disabilities and Indonesian's characteristic; the author recommends an alternative to set standard points to be contained in regulation of persons with disabilities in each region. It can be understood as a more specific explanation from the Act No. 19 Year 2011 on Convention on the Rights of Person with Disabilities. Local regulation that is developed by each province or district/city must support accessibility standards for persons with disabilities. The points of standardization to be put into consideration by local governments in establishing regulations concerning persons with disabilities are:

1. Preparation of comprehensive and integrated regulation in autonomous region. In designing local regulation, the executive as executor and the legislative as decision maker need to share their idea. The fulfillment of the rights of persons with disabilities which are governed by local regulations must be interpreted and implemented in a concrete way by the executive. Substantive local regulations should prioritize proper treatment for persons with disabilities. The paradigm of equality is automatically attached to each of the regions as the subject of law and guaranteed by the Constitution; therefore, it is ineffective to set the needs of basic human rights in local regulation.

2. The fulfillment of the rights for persons with disabilities is in every aspects of life of the state. Thus, local regulations to be made should refer to other regulations comprehensively. Law No. 19 Year 2011 as the basic and main regulation cannot stand alone. The legal basis to design local regulations must also consider the general needs of persons with disabilities in Law No. 4 Year 1997 on Person With Disabilities, Law No. 39 Year 1999 on Human Rights, Law No. 23 Year 2002 on Children Protection, Law No. 36 Year 2009 on Medical, Law No. 25 Year 2009 on Public Services, and Law No. 11 Year 2009 on Social Welfare. 
3. In accordance to Malaysian reference on the fulfillment of the rights of person with disabilities, the author's recommends specific regulation in local regulation on some points:

a. Budget

Malaysian government has a program to provide financial support to empower and maintain citizen who needs special treatment like persons with disabilities. Learning from this reference, local government of Indonesia should set specific amount of budget to be used in local regulation, or at least to set a budget for the empowerment of persons with disabilities as one the priority.

\section{b. Information/Data System}

To help local government in setting the budget for the empowerment of persons with disabilities, each region should have reliable data on number of person with disabilities. KAD $\mathrm{OKU}$ in Malaysia can be a reference for systematic data of persons with disabilities. With this special card, government may access needed information on condition of person with disabilities. Moreover, the holder of this special card can get special treatment to access public facility.

Every region is expected to have special regulation on specific mechanism of data collection, information system, and institution that responsible in collecting and processing the data.

\section{c. Public Facilities}

The content of Local Regulation should concern with obligations to provide proper access to facilitate persons with disabilities in public facilities. To depict public facilities accessible for persons with disabilities, the author provided some pictures of Malaysian public facilities to be used as reference.

Malaysia is one step ahead in providing proper facilities for persons with disabilities. This is because the local regulation that regulates public facilities supports the needs of person with disabilities like local regulation about building standard, public transportation, or accessibility in education. Consequently, local 
government needs to adjust local regulation to fulfill the rights of person with disabilities.

\section{CONCLUSION}

Basic Disabilities Law on Law No. 4 of 1997 on Persons with Disabilities supported by the Law No. 19 of 2011 on Ratification of the Convention on the Rights of Persons with Disabilities, have become a standard to set equality of human rights, embodied ideal norms, and concept empowered by the state and owned by the people of Indonesia. However, the fulfillment of the law is not easy. Although supported by legal standard, justice for persons with disabilities is still uncertain. Equality for persons with disabilities becomes part of the dynamics of law in Indonesia and sadly, many people have to be victims. Many factors contributed to the problems, including the role of government on all policies and regulation, current facilities, and limited knowledge about the regulation. To build Indonesia as a prosperous and fair country especially for persons with disabilities, synergic struggle and communication of all parties are needed. When the strategic outposts experience similar problems, these ideal conditions will certainly hard to be achieved. So far, Indonesian problems are so complex - the effort to provide equality for citizen's rights is worsened by poor systems.

\section{REFERENCES}

\section{Book}

P.J. Suwarno, Pancasila Indonesian National Culture, Jakarta, Canisius, 1993

Shad Saleem Faruqi, Document of Destiny: The Constitution of the Federation of Malaysia, Malaysia: Star Publications Berhad, 2008

Erwin Chemerinsky, Constitutional Law: Principles and Policies, Aspen Law and Business, New York, 1997

Asshiddiqie, Freedom of Association, Dissolution of Political Parties, and the Constitutional Court, Konpress, Jakarta, 2005

Satya Arinanto, Human Rights in Political Transition in Indonesia, FHUI HTN Study Center, Jakarta, 2003

Read Peter Baehr, Pieter van Dijk et al, eds,

Principal International Instruments on Human Rights, Yayasan Obor Indonesia, Jakarta, 2001

Ernest W. Huffcut, Elements of the Law of Agency, Beard Books, 1999

Udiyo Basuki, Perlindungan HAM dalam Negara Hukum Indonesia: Studi Ratifikasi Konvensi Hak-hak Disabilitas (Convention on the Rights of Person with Disabilities), SOSIO-RELIGIA, Vol. 10, No. 1 Februari 2012

Pozzan E. Disability and International Standards. Jakarta: ILO Jakarta. 2013 
Saharuddin Daming ,. Marjinalisasi Hak Politik Penyandang Disabilitas. Penerbit Komnas HAM, Jakarta. 2012

Journal and Online Article

Eva Rahim Kasim, Chronological Efforts Ratification The Convention on the Rights of Persons With Disabilities in Indonesia, paper presented at Seminar Day of CRPD and its' Implementation in Form Inclusive Local Development Policy in West Sumatra, Padang, February 4, 2013. https: // www.academia.edu/4728310/KRON OLOGIS_UPAYA_RATIFIKASI_T HE_CONVENTION_ON_THE_RIG HTS_OF_PERSONS_WITH_DISA BILITIES_KONVENSI_HAKHAK_PENYANDANG_DISABILIT AS_DI_INDONESIA_Oleh_Eva_Ra hmi_Kasim

Rebecca Wallace, International Human Rights Text and Materials, London: Sweet \& Maxwell, 1997

Social Ministry of Australia, Planning assessment urgent cases http://www.ndis.gov.au

/sites/default/files/documents/og_pla nning_assessment_urgent_cases.pdf

Abdul Munawar, Malaysia dan Australia, Surga bagi Kaum Disabilitas, http://health.liputan6 .com/read/771028/malaysia-danaustralia-surga-bagi-kaumdisabilitas.

ILO,Inklusi Penyandang Disabilitas di Indonesia.

http://www.ilo.org/wcmsp5/groups /public/---asia/---ro-bangkok/---ilojakarta/documents/publication/wcms _233426.pdf

Iffah Nur Arifah, Kesadaran Hukum Difabel Indonesia Rendah, http://www.radioaustralia.net.au/indo nesian/2014-05-01/kesadaranhukum-difabel-indonesiarendah/1303744

Persepsi, Ribuan Orang Difabel di Klaten Tak Dapat Jaminan

Sosial,http://www.persepsi-

klaten.org/sosial/ribuan-orang-

difabel-di-klaten-tak-dapat-jaminansosial,

\section{Convention and National Law}

International Convention on The Rights of Persons with Disabilities

Constitution 1945

Law Number 39 Year 1999 of Human Rights

Law Number 19 Year 2011 of Ratification of Convention on The Rights of Persons with Disabilities 